\title{
Homoseksualizm w prawodawstwie biblijnego Izraela
}

\author{
Homosexuality in the Biblical Law
}

\author{
BARBARA STRZA $ヒ$ KOWSKA \\ Uniwersytet Kardynała Stefana Wyszyńskiego w Warszawie \\ bstrzalkowska@wp.pl, ORCID: 0000-0002-6306-4322
}

\begin{abstract}
Streszczenie: Niniejszy artykuł ma na celu przyjrzenie się tematowi homoseksualizmu w prawodawstwie biblijnego Izraela i analizę konkretnych przepisów dotyczących tego zagadnienia. Zagadnienie praktyk homoseksualnych pojawia się w prawodawstwie Tory wyraźnie dwukrotnie, w Kpł 18,22 oraz Kpł 20,13, w obu przypadkach obok innych praktyk życia intymnego zakazywanych przez Prawo. Oba teksty zostały w artykule omówione wraz z ich kontekstem, a następnie podano możliwe ich interpretacje - te tradycyjne i te wysuwane w ostatnich kilkunastu latach, które próbują ukazać treść biblijnego prawodawstwa jako niebędącego klarownie przeciw relacjom homoseksualnym (inaczej niż było to ujęte w tradycji żydowskiej i chrześcijańskiej). Artykuł dodatkowo - w omawianym kontekście prawodawstwa dotyczącego homoseksualizmu - analizuje dwa możliwe teksty mówiące o męskiej prostytucji sakralnej (Pwt 23,18-19 oraz ewentualnie także Kpł 18,21).
\end{abstract}

Słowa kluczowe: homoseksualizm; Kpł 18,22; Kpł 20,13; Pwt 23,18-19; Kpł 18,21; współczesne interpretacje biblijnego prawodawstwa dotyczące homoseksualizmu; prawodawstwo biblijnego Izraela; męska prostytucja sakralna

\begin{abstract}
The purpose of this article is to look at the topic of homosexuality in ancient Israel's legislation and to analyze the specific regulations on this issue. The issue of homosexual acts appears clearly twice in the Torah, in Leviticus 18:22 and 20:13, in both cases alongside other intimate practices prohibited by Law. Both texts are discussed in the article together with their context, and then possible interpretations - the traditional ones, and those proposed in recent years. The latter try to demonstrate that the content of biblical legislation is not clearly opposed to homosexual relations (unlike how it was interpreted in the Jewish and Christian traditions). The article additionally - in the discussed context of the legislation on homosexuality - analyses two biblical texts possibly dealing with male sacred prostitution (Deut 23:18-19 and possibly also Leviticus 18:21).
\end{abstract}

Keywords: Homosexuality; Lev 18:22; Lev 20:13; Deut 23:18-19; Lev 18:21; contemporary interpretations of the biblical laws on homosexuality; legislation of ancient Israel; male sacred prostitution

W ostatnich latach kwestia homoseksualizmu w Biblii stała się popularnym tematem badawczym. Przyglądając się naukowej literaturze biblijnej, łatwo dostrzec wzrost zainteresowania tym tematem w ciągu ostatnich 20-30 (a zwłaszcza ostatnich kilku!!) lat, co - jak się wydaje - jest przede wszystkim efektem zmian dotykających

1 Nie sposób wyliczyć wszystkich publikacji na ten temat, jednak dla zobrazowania zamieszczam wykaz wyłącznie publikacji książkowych: Vasey, Strangers and Friends. A New Exploration of Homosexuality and 
współczesne społeczeństwa naszego kręgu kulturowego, w których temat ten staje się także elementem - czasem głośnej - debaty publicznej. Dawniejszych opracowań naukowych jest znacznie mniej², a nawet bardzo popularne starsze opracowania biblijne temat homoseksualizmu traktują niejako pobocznie ${ }^{3}$. Zmiana dotyczy nie tylko liczby opracowań, ale także postrzegania tego tematu: czytając dawniejsze opracowania przepisów z Księgi Kapłańskiej (18,22 i 20,13), nie odnosi się wrażenia, by były one niejasne lub nieaktualne, ani by je kwestionowano. Wątpliwości dotyczące tych tekstów pojawiają się tym częściej, im bliżej naszych czasów jesteśmy. Warto zatem zadać pytanie, skąd taka zmiana w interpretacji biblijnej? Czy zmieniło się coś w samym tekście biblijnym? Czy to raczej w naszym społeczeństwie dokonało się coś, co sprawia, że chcemy inaczej widzieć tekst i tradycję jego interpretacji?

By uniknąć jakiejkolwiek ideologizacji w badaniach biblijnych, należy faktycznie przyjrzeć się omawianym tekstom bez żadnych przedzałożeń. Niniejszy artykuł ma na celu omówienie tematu homoseksualizmu w prawodawstwie biblijnego Izraela i analizę konkretnych przepisów dotyczących tego zagadnienia. Nie sposób nie odnieść się także do wspomnianych współczesnych badań tych tekstów.

Na początku trzeba zauważyć, że Biblia - co zrozumiałe - nigdzie nie używa terminu „homoseksualizm”, który jest pojęciem współczesnym, XIX-wiecznym ${ }^{4}$ (choć

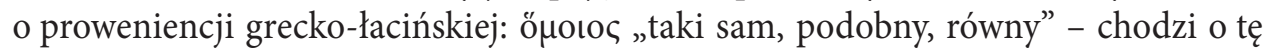
samą płeć - oraz sexualis - termin odnoszący się do życia płciowego ${ }^{5}$ ). Po drugie, w każdym z przypadków, w którym w prawodawstwie biblijnym mowa jest o intymnych relacjach między osobami tej samej płci, tekst biblijny ma na myśli konkretne akty homoseksualne (zawsze w Prawie zakazane), a nie orientację, skłonności czy całą złożoność psycho-fizyczną i społeczną tego zagadnienia i tego, co współcześnie

the Bible; Brawley (red.), Biblical Ethics and Homosexuality. Listening to Scripture; Wold, Out of Order. Homosexuality in the Bible and the Ancient Near East; Nissinen, Homoeroticism in the Biblical World; Balch (red.), Homosexuality, Science, and the "Plain Sense" of Scripture; Helminiak, What the Bible Really Says About Homosexuality?; Gagnon, The Bible and Homosexual Practice; Gagnon - Via, Homosexuality in the Bible; Rogers, Jesus, the Bible, and Homosexuality; Hornsby - Stone (red.), Bible Trouble. Queer Reading at the Boundaries of Biblical Scholarship; Himbaza - Schenker - Edart, The Bible on the Question of Homosexuality. Do tego należałoby doliczyć blisko sto artykułów naukowych poświęconych tematowi homoseksualizmu w Biblii, powstałych tylko w ciągu ostatnich 20 lat!

2 Większość publikacji, zarówno książkowych, jak i artykułów, odnoszących się do kwestii homoseksualizmu w Biblii powstała po roku 2000; spośród starszych publikacji wyróżnia się książka: Bahnsen, Homosexuality. A Biblical View; oraz artykuły, np.: Gilbert, „La Bible et l'homosexualité”, 78-95; Wenham, „The Old Testament Attitude to Homosexuality”, 359-363; Becker, „Zum Problem der Homosexualität in der Bibel", 36-59.

3 Przykładem może być choćby popularny słownik biblijny Anchor Biblie Dictionnary, który nie opracowuje odrębnego hasła „Homosexuality”, a jedynie wspomina o homoseksualizmie w innych kontekstach (prostytucji, kar i przestępstw, Listu do Rzymian, seksualności).

4 Himbaza - Schenker - Edart, The Bible on the Question of Homosexuality, IX-X.

5 Por. np. Strojnowski - Greniuk, „Homoseksualizm”, 1194-1195. 


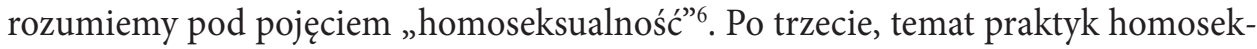
sualnych nie jest ani głównym zagadnieniem, ani nawet jednym $\mathrm{z}$ ważniejszych przepisów zawartych w Torze, ale stanowi zawsze część większej całości, która odnosi się do bardzo różnych nieuporządkowanych relacji sfery seksualnej człowieka (zawsze - co trzeba zauważyć - ocenianych negatywnie: Biblia będzie widziała jedyną dobrą realizację życia ludzkiego w sferze seksualnej wyłącznie w relacjach małżeńskich, kobiety i mężczyzny).

Zagadnienie praktyk homoseksualnych pojawia się w prawodawstwie Tory wyraźnie dwukrotnie, w Kpł 18,22 oraz Kpł 20,13, w obu przypadkach obok innych praktyk życia intymnego zakazywanych przez Prawo. Oba teksty przynależą do części Księgi Kapłańskiej zwanej Kodeksem Świętości (H; Kpł 17-27) i oba są ze sobą powiązane: pierwszy zawiera przepis dotyczący tej sfery życia (zakaz aktów homoseksualnych), drugi - stanowi jego powtórzenie i penalizację (objęcie czynu lub działania systemem kar) w razie jego nieprzestrzegania.

Obok tych tekstów prawodawstwo biblijne odnosi się jeszcze dwukrotnie do aktów homoseksualnych, jednak już w kontekście nieco bardziej złożonym, dotyczącym prostytucji sakralnej męskiej (nie wszyscy ten tekst interpretują w kategoriach aktów homoseksualnych ${ }^{7}$ - w Pwt 23,18-19 oraz Kpł 18,21 .

\section{Kpł 18,22 i 20,13 - kontekst i interpretacja}

Ponieważ Kpł 18,22 i 20,13 są jedynymi tak wyraźnymi i bezpośrednimi prawnymi rozporządzeniami dotyczącymi aktów homoseksualnych w Biblii, a także ze względu na ich powiązanie (kontekstualne i treściowe), większość opracowań zestawia je ze sobą i omawia je razem ${ }^{9}$. Pierwszy z przepisów znajduje się w kontekście rozdziału 18, który w odniesieniu do świętości małżeństwa i rodziny ukazuje rozmaite

6 „[... the phenomenon of a homosexual orientation, while certainly real, was unknown to the authors of the Bible. Certainly the Scriptures refer to samesex relations; but they do not refer to them in quite the same way that we do today" (Himbaza - Schenker - Edart, The Bible on the Question of Homosexuality, X).

7 Por. Joosten, „A New Interpretation of Leviticus 18:22”, 1.

8 Na temat takiego ujęcia obu praw w możliwej interpretacji prostytucji sakralnej zob. np. Sprinkle, „Sexuality", 751 .

9 Na ich temat zob.: Walsh, „Leviticus 18:22 and 20:13”, 201-209; Snyman, „Help Levitikus 18:22 en 20:13”, 968-981; Swart - Human, „Hoe Bruikbaar is Levitikus 18 en 20”, 455-481; Caron, „Le Lévitique condamnerait-il l'homosexualité?”, 27-49; Olyan, „And with a Male You Shall Not Lie”, 57-83; Hieke, „Kennt und verurteilt das Alte Testament Homosexualität?”, 19-52; Mathias, „Queering the Body”, 17-40; Dershowitz, „Revealing Nakedness”, 510-526; Hollenback, „Who is Doing What to Whom Revisited”, 529-537; Römer, „Homosexualität und die Bibel”, 47-63; Dershowitz, „Response”, 625-628; Sklar, „The Prohibitions Against Homosexual Sex”, 165-198; Joosten, „A New Interpretation of Leviticus 18:22”, 1-10; Töyräänvuori, „Homosexuality”, 236-267; o omawianych tekstach wspomina m.in. Martin Leuenberger („Geschlechterrollen und Homosexualität im Alten Testament”, 206-229). Warto zauważyć, że wszystkie publikacje powstały po roku 2000. 
nadużycia w tej sferze życia, także te dotyczące seksualności; drugi zaś jest częścią rozdziału 20, który z kolei - obok powtórzenia ( $w$ nieco innej kolejności) rozmaitych zakazów także w kontekście rodziny i małżeństwa (ww. 9-21, przy czym seksualne relacje są omówione od w. 10) - przewiduje kary za niezachowanie owych przepisów.

Oba teksty - Kpł 18,22 i 20,13 - brzmią (TM za BHQ) ${ }^{10}$ :

Kpł 18,22:

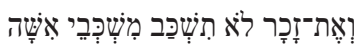

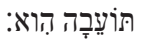

A z mężczyzną (dosł. z „samcem”, z „rodzajem męskim”) nie będziesz kładł się (także: „leżał”, po polsku lepiej „spał”) tak jak leży się z kobietą (dosł. „na łożach kobiety”; wyrażenie idiomatyczne).

To obrzydliwość.

Kpł 20,13:

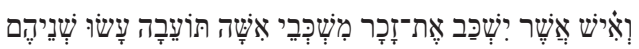

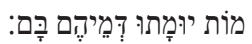

A mężczyzna, który kładzie się (dosł. „leży”, po polsku lepiej „śpi”) z mężczyzną (dosł. $\mathrm{z}$,samcem”, z „rodzajem męskim”), tak jak leży się z kobietą (dosł. „na łożach kobiety”;

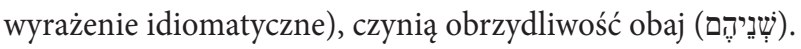

Winni są śmierci (dosł. „śmiercią umrą", „na pewno winni umrzeç”). Krew ich na nich.

Kontekst tych przepisów jest kluczem do ich interpretacji. Najpierw rozdział 18 wymienia 14 zakazów dotyczących kazirodztwa (Kpł 20 powtórzy 12 z nich) w ujęciu różnych zależności rodzinnych (ww. 18,1-18) ${ }^{11}$, zaś sam przepis z 18,22 bezpośrednio poprzedzają: zakaz współżycia z kobietą w czasie menstruacji (Kpł 18,19; powtórzony po szerszym omówieniu tego zagadnienia w Kpł $15^{12}$ ), zakaz współżycia z żoną bliźniego (Kpł 18,20), zakaz ofiarowania dzieci (*nasienia, hebr. ז̊? leka” (Kpł 18,21), które jako jedyne, jak się wydaje, odbiega tematycznie od kwestii grzechów sfery seksualnej ${ }^{13}$. Bezpośrednio po tym wersecie pojawia się przykazanie

10 Jeden z najnowszych tomów krytycznego wydania BHQ opracowuje właśnie Księgę Kapłańską; por. Himbaza (red.), ויקרא Leviticus. Wszystkie odwołania do hebrajskiego tekstu w niniejszym artykule są za BHQ.

11 Na ich temat zob. Schenker, "What Connects the Incest Prohibitions”, 162-185. A dawniej: Bigger, „The Family Laws of Leviticus 18”, 188-203.

12 Na jego temat zob.: Strzałkowska, Rozporządzenia dotyczace kobiet w Kpł 15; Strzałkowska, „Kobiety w świetle przepisów Księgi Kapłańskiej”, 5-44.

13 Por. Tronina, Księga Kapłańska, 270-272. Choć Job M. Sprinkle („Sexuality”, 751) widział w ich możliwe nawiązanie do prostytucji sakralnej (użyty w tym wersecie termin זֶר rozumiejąc nie jako "potomstwo", a bardziej dosłownie jako „nasienie”). 
zakazujące współżycia mężczyzny z mężczyzną, które jako jedyne z dotychczas wyli-

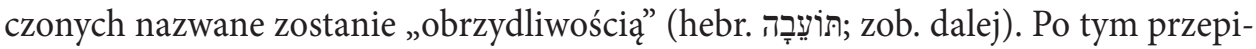
sie pojawia się jeszcze w Kpł 18,23 zakaz jakichkolwiek relacji seksualnych, zarówno kobiet, jak i mężczyzn (wyjątkowo wymienia się tu obie płcie), ze zwierzętami, nazwane innym mocnym hebrajskim terminem („רֶ (,sromota”, „pomieszanie”), który wywodzi się „od rdzenia bll ('mieszać) i wskazuje wprost na naturę tego zboczenia, które narusza granice gatunków, ustanowione przez Boga (Rdz 1,11n.21.28n)"14.

Przykazanie dotyczące relacji homoseksualnych $\mathrm{z}$ wersecie 18,22 (podobnie jak w 20,13) jest zatem częścią większej całości i nie jest specjalnie wyróżnione, choć co ważne - w pierwszej perykopie z rozdziału 18 biblijny prawodawca zdaje się stopniować wagę grzechów: od zakazów współżycia z żoną podczas menstruacji przez zakaz cudzołóstwa z żoną bliźniego, później zakaz ofiarowania dzieci Molekowi, po - kończący perykopę - zakaz współżycia z mężczyzną, zwany „obrzydliwością”

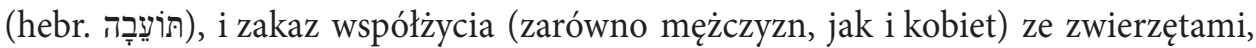
zwany „sromotą", „pomieszaniem” (hebr. תֶֶֶ)

Warto zauważyć, że przykazanie z wersetu 18,22 - tak jak całe prawodawstwo tej części Księgi Kapłańskiej (zarówno rozdz. 18, jak i 20) - skierowane jest do mężczyzn i przedstawia zakazy z męskiej perspektywy (na przykład zakazy współżycia z żoną bliźniego, matką, siostrą, córką, teściową, synową itd. nigdy nie są odwrócone i tekst biblijny nie zwraca się analogicznie do kobiet, by nie sypiały z mężem bliźniej, ojcem, bratem, synem, teściem, zięciem). Przy założeniu, że Prawo w społeczności patriarchalnej biblijnego Izraela tworzone było przez mężczyzn i dla mężczyzn - nie powinno dziwić to, że brzmi ono jakby dotyczyło wyłącznie mężczyzn. Nie oznacza to naturalnie, że kobiet te przepisy nie dotyczyły, ale że na mężczyznach spoczywało główne zadanie przestrzegania ${ }^{16}$ Prawa. Dlatego omawiany werset mówi o relacjach homoseksualnych z mężczyzną, a nie relacjach między kobietami, choć z pewnością nie dlatego, iż te drugie byłyby dozwolone ${ }^{17}$. Jak zauważają autorzy jednego $\mathrm{z}$ nowszych opracowań:

Prawo zawsze może mieć wiele zastosowań, które są ukryte w jego sformułowaniu. Staje się ono jasne w świetle nowych sytuacji, które można interpretować analogicznie do tych przewidzianych dosłownie w tekście. Dlatego możemy stwierdzić ponad wątpliwość, że zgodnie z Biblią stosunki seksualne między kobietami są również zabronione ${ }^{18}$.

14 Tronina, Księga Kapłańska, 274.

15 Na temat owego stopniowania i możliwych interpretacji całego kontekstu Kpł 18 zob. Milgrom, Leviticus 17-22, 1514-1584. Jacob Milgrom (Leviticus 17-22, 1531) przekazuje ciekawy schemat owych zakazanych czynności seksualnych.

16 Na ten temat zob. Strzałkowska, „Przemoc wobec kobiet”, 9-29 (zwł. 19).

17 Na ten temat zob. Milgrom, Leviticus 17-22, 1568.

18 „A law is always capable of a number of applications that are implied in its formulation. This becomes clear in the light of new situations that are interpreted analogously with those envisaged by the text. This 
Tak samo ów brak odniesienia do kobiet w omawianym przepisie interpretowała tradycja żydowska, zawarta choćby w Talmudzie ${ }^{19}$, choć niektóre współczesne interpretacje rabinów mówią, że w zakazie Kpł 18,22 może chodzić o nieczystość męskich narządów płciowych podczas seksu analnego, a ponieważ podczas seksu lesbijskiego nie dochodzi do penetracji, może on nie być w Torze zakazany ${ }^{20}$.

Sama treść obu zakazów z Kpł 18,22 i 20,13 wydaje się klarowna i radykalna w swoim przesłaniu. Ciekawe, że gdy mowa o zakazanych relacjach seksualnych z mężczyzną (zgodnie ze sformułowaniem prawodawcy), zarówno tekst 18,22, jak i 20,13 używają określenia זָ ִָ (dosł. „rodzaj męski”, „samiec”), a nie terminu („mężczyzna”). Wydaje się, że użycie właśnie tego terminu, o dość dosadnej etymologii, nawiązującej do relacji seksualnych ${ }^{21}$ (pośród 82 przypadków występowania w BH odnoszony zarówno do ludzi, jak i do zwierząt), ma podkreślić kategoryczność samego przesłania obu powiązanych przepisów o zakazie współżycia mężczyzny z mężczyzną.

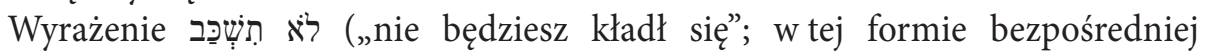
w w. 18,22, zaś w w. 20,13 w formie kazuistycznej albo warunkowej: הֶ, , , a mężczyzna, który leży z mężczyzną"22) w tych i w wielu innych wypadkach w Biblii jest eufemistycznym określeniem relacji seksualnych, co do tego nie ma wątpliwości. Podobne określenia eufemistyczne pojawiały się także w innych kulturach, również współcześnie niemal we wszystkich językach europejskich, także w języku polskim, gdy mówimy o „sypianiu z kimś” - nie chodzi faktycznie o czynność „spania”, a o „akt seksualny”.

Najwięcej dyskusji w interpretacjach treści omawianych przepisów wzbudziło

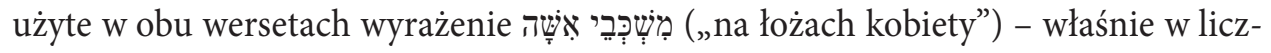
bie mnogiej. Tradycyjnie postrzegano je jako eufemizm na określenie relacji seksualnej. W takiej wersji występuje on także np. w Targumie Onkelosa; zaś LXX oraz Peš, choć zmieniają obecną w TH liczbę mnogą na pojedynczą, to nie zmieniają klarownej interpretacji tekstu. Jan Joosten w nowym opracowaniu udowadnia, iż wyrażenie to jest w TH w liczbie mnogiej (tak jak w Rdz 19,4 oraz Kpł 20,13), ponieważ oznacza

is why we can state the probability that, according to the Bible, sexual relations between women is also prohibited" (Himbaza - Schenker - Edart, The Bible on the Question of Homosexuality, 70). Greenberg, Wrestling With God and Man, 86-90.

20 „Lesbian sex simply does not include a penis, and only sexual acts involving penile penetration were under the legislative scrutiny of the Torah". Por. Greenberg, Wrestling With God and Man, 86.

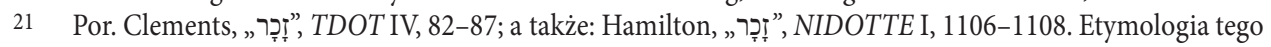
słowa, choć złożona, oznacza zasadniczo nawiązanie do czynności seksualnych męskich, w odróżnieniu od żeńskich czynności wyrażonych w hebrajskim terminie נְְִָּ - pochodzącym od rdzenia oznaczającego

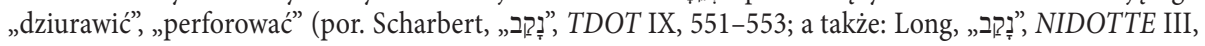
149-150). Oba terminy są użyte między innymi w pierwszym opowiadaniu o stworzeniu świata i człowie-

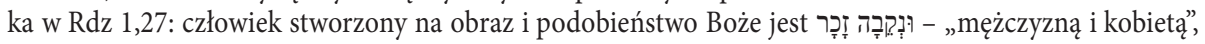
a dosadniej: „samcem i samicą”, „rodzajem męskim i żeńskim”, człowiek jest stworzony dwojga płci i tak wypełnia swoją misję w świecie.

22 Himbaza - Schenker - Edart, The Bible on the Question of Homosexuality, 61. 
podwójne (małżeńskie) łoże, co prowadzi do interpretacji tego wyrażenia właśnie jako eufemistycznego określenia relacji seksualnej ${ }^{23}$ (Joosten idzie jednak w swojej interpretacji dalej, ukazując, że w całym przepisie chodzi o zakaz współżycia z żonatym mężczyzną, a nie z mężczyzną w ogóle $\left.{ }^{24}\right)$.

Trzeba zauważyć, że zarówno żydowskie, jak i chrześcijańskie przekłady obu tekstów zawsze tłumaczą ten rzeczownik (czy w liczbie mnogiej, czy pojedynczej) czasownikowo i opisowo, odnosząc go do relacji seksualnej. Klarownie widać to na przykładzie Wulgaty, która w obu wersetach w tym miejscu używa terminu „coitus", oznaczającego współżycie seksualne (podobnie jak niektóre tradycje targumiczne, np. Targum Neofiti i Targum Jonatana). Jacob Milgrom zauważa, że liczba mnoga użyta w TH zawsze pojawia się w kontekście zabronionych relacji cielesnych

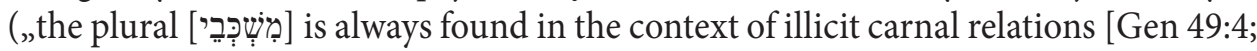
Lev 18:22; 20:13]"). ${ }^{25}$ Podobnie zauważali także inni, np. Innocent Himbaza. ${ }^{26}$ Ostatnio podjęto $\mathrm{z}$ tym poglądem dyskusję. Jedna $\mathrm{z}$ badaczek $\mathrm{z}$ Uniwersytetu w Helsinkach, Joanna Töyräänvuori, w artykule z 2020 r., odczytując tekst dosłownie, próbowała udowodnić, że w obu tekstach chodzi o to, by mężczyzna nie kładł się na łożu kobiety jednocześnie $\mathrm{z}$ innym mężczyzną - chodzi o zakaz współżycia dwóch mężczyzn jednocześnie $z$ jedną kobietą (a nie mężczyzn ze sobą), co powodowałoby, iż trudno byłoby ustalić, kto jest ojcem dziecka poczętego w wyniku takiej relacji2 ${ }^{27}$. Powyższej interpretacji przeczy zarówno gramatyka, jak i tradycja lektury tych tekstów, nawet ta sięgająca czasów biblijnych, przedchrześcijańskich, zawarta w LXX, powstała w III w. przed $\mathrm{Chr}^{28}$, w najstarszym greckim ich przekładzie. Werset 18,22 brzmi w LXX:

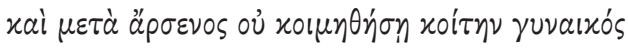

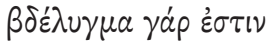

A z mężczyzną nie będziesz spał na łożu kobiety (w znaczeniu „jak z kobietą").

[To] bowiem jest obrzydliwość!

LXX w tym wypadku wyjątkowo wiernie przekłada tekst hebrajski, używając (jak w Rdz 1,27) terminu äponv, odpowiadającego hebr. זָ i używanego częściej w znaczeniu: „rodzaj męski”, „samiec”. Użyte w wersecie słowo koítๆ („łoże), zarówno w LXX, jak i NT, często eufemistycznie oznacza „łoże małżeńskie” - i w konsekwen-

\footnotetext{
23 Joosten, „A New Interpretation of Leviticus 18:22”.

24 Joosten, „A New Interpretation of Leviticus 18:22”, 1-10 (zwł. 5-7).

25 Milgrom, Leviticus 17-22, 1569.

26 Himbaza (red.), ויקרא Leviticus, 108*.

27 Töyräänvuori, „Homosexuality”, 236-267.

28 Na temat datacji Tory (i Księgi Kapłańskiej) w LXX zob. np.: Strzałkowska, „Księga Kapłańska w Septuagincie”, 67-84 oraz Strzałkowska, „Księga Rodzaju w Septuagincie”, 95-121.
} 
cji „współżycie seksualne”. Najważniejsza jednak dla interpretacji tego wersetu wydaje się użyta w nim gramatyczna forma: termin ảpoøv użyty jest tu w formie accusa-

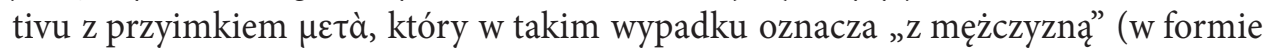
z genetivusem $\mu \varepsilon \tau$ à oznaczałoby „po”). Tekst nie pozostawia wątpliwości, że chodzi o współżycie dwóch mężczyzn ze sobą tak, jak z kobietą. W ten sam sposób zresztą interpretuje to tradycja, zarówno żydowska ${ }^{29}$, jak i chrześcijańska. Podobnie w od-

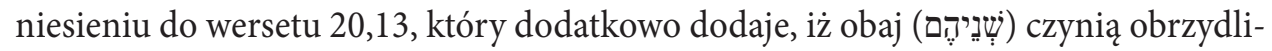

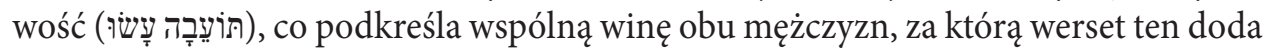
na końcu karę (zob. dalej).

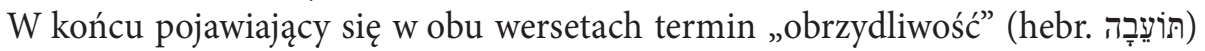
występuje w Biblii dość często (118 razy $^{30}$; zaś w czasownikowej formie 23 razy $^{31}$ ), a w prawodawstwie Tory użyty jest wyłącznie w odniesieniu do wykroczeń w dwóch sferach: seksualnej i - przede wszystkim - kultycznej. W odniesieniu do sfery seksualnej pojawia się w omawianym kontekście kilkakrotnie (por. Kpł 18,22.26-27.29-30; 20,13 - tu użyte tylko w odniesieniu do homoseksualizmu; a także w innym miejscu, raz w odniesieniu do noszenia ubrań męskich przez kobiety, co identyfikowane jest przez niektórych - np. J. Milgroma - z transwestytyzmem ${ }^{32}$, co jest, według Pwt 22,5, „obrzydliwością"; oraz jeszcze raz - w kontekście rodzinnym - ponownego małżeństwa z kobietą wcześniej porzuconą; por. Pwt 24,4). Określając wykroczenia sfery

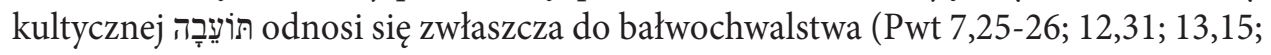
14,$3 ; 17,1.4 ; 18,9.12 ; 20,18 ; 23,19 ; 25,16 ; 27,15 ; 32,16$;). Owo bałwochwalstwo jest określone mianem „obrzydliwości” jeszcze w Księgach Królewskich (por. 1 Krl 14,24; $2 \mathrm{Krl} 16,3 ; 21,2.11 ; 23,13$ i in.) i późniejszych ${ }^{33}$.

Połączenie tych dwóch sfer wydaje się mieć istotne znaczenie, bowiem wykroczenia homoseksualne mogły być praktykowane właśnie w kontekście sakralnym - męskiej prostytucji świątynnej - zwłaszcza u innych narodów (do tego mogłoby także nawiązywać wspomniane prawo z Pwt 23,18-19, a może nawet Kpł 18,2134, jednak oba teksty nie są jednoznaczne ${ }^{35}$; zob. dalej).

29 Na temat żydowskiej interpretacji tych tekstów i podejścia do homoseksualizmu zob. Greenberg, Wrestling With God and Man (na temat Księgi Kapłańskiej zob. zwł. strony 74-85).

Rdz 43,32; 46,34; Wj 8,22; Kpł 18,22.26-27.29-30; 20,13; Pwt 7,25-26; 12,31; 13,15; 14,3; 17,1.4; 18,9.12; 20,$18 ; 22,5 ; 23,19 ; 24,4 ; 25,16 ; 27,15 ; 32,16 ; 1 \mathrm{Krl} 14,24 ; 2 \mathrm{Krl} 16,3 ; 21,2.11 ; 23,13 ; 2 \mathrm{Krn} 28,3 ; 33,2 ; 34,33$; 36,8.14; Ezd 9,1.11.14; Ps 88,9; Prz 3,32; 6,16; 8,7; 11,1.20; 12,22; 13,19; 15,8.9.26; 16,5.12; 17,15; 20,10.23; 21,$27 ; 24,9 ; 26,25 ; 28,9 ; 29,27 ;$ Iz 1,$13 ; 41,24 ; 44,19 ;$ Ir 2,7; 6,15; 7,10; 8,12; 16,18; 32,35; 44,4.22; Ez 5,9.11; $6,9.11 ; 7,3.4 .8 .9 .20 ; 8,6.9 .13 .15 .17 ; 9,4 ; 11,18.21 ; 12,16 ; 14,6 ; 16,2.22 .36 .43 .47 .50 .51 .58 ; 18,12.13 .24 ; 20,4$; $22,2.11 ; 23,36 ; 33,26.29 ; 36,31 ; 43,8 ; 44,6.7 .13 ; \mathrm{Ml} 2,11$.

31 Milgrom, Leviticus $17-22,1569$.

32 Ten tekst nie jest łatwy do interpretacji, na jego temat zob. Lemański, „(Post-)deuteronomistyczny zakaz transwestytyzmu (Pwt 22,5)?", 77-104.

33 Por. na temat tego rdzenia: Grisanti, „בְָָּ", NIDOTTE IV, 314-318.

34 Por. Sprinkle, „Sexuality”, 751.

35 Joosten, „A New Interpretation of Leviticus 18:22”, 1. 
To ostatnie stwierdzenie jest kluczowe dla interpretacji obu przepisów: dla biblijnego prawodawcy bardzo ważne było, by Izrael nie powielał praktyk proponowanych przez inne narody, a czyny homoseksualne były takimi, w których odrzuceniu Izrael miał się odróżniać od innych (Gordon J. Wenham cały bliższy kontekst - ww. 19-23 - traktuje jako całość zatytułowaną: „Other Canaanite Customs to Be Avoided” [Inne praktyki kananejskie, których należy unikać]; naturalnie pomiędzy tymi praktykami umieszcza te homoseksualne $\left.{ }^{36}\right)$. O to odróżnienie od innych narodów będzie też chodziło w całym szerszym kontekście rozdzialu 18 i całego Kodeksu Świętości (H). W ten sposób Izrael się uświęcał - hebr. קָדí „święty” oznaczać będzie także (zwłaszcza w późniejszej interpretacji tych tekstów, a może także jako ich owoc) „oddzielony”.

Warto zwrócić uwagę na uzasadnienie wszystkich tych praw, odnoszących się do sfery seksualnej, które pojawia się na końcu rozdziału 18. Po wyliczeniu wszystkich wykroczeń tej sfery, padają słowa, które powinny być kluczem do umotywowania przepisów:

Tymi wszystkimi rzeczami się nie plugawcie, bo tymi wszystkimi rzeczami plugawiły się narody, które wypędzam przed wami. Także i ziemia stała się nieczysta. Ukarałem ją więc za jej winę, a ziemia wypluła swoich mieszkańców. Strzeżcie więc ustaw i wyroków moich, nie czyńcie nic z tych obrzydliwości. [...] Bo wszystkie te obrzydliwości czynili mieszkańcy ziemi, którzy byli przed wami, a ziemia została splugawiona. Ale was ziemia nie wyplunie z powodu splugawienia jej, tak jak wypluła naród, który był przed wami. Bo każdy, kto czyni jedną z tych obrzydliwości, wszyscy, którzy je czynią, będą wyłączeni spośród swojego ludu. Będziecie więc przestrzegać mego zarządzenia, abyście nie czynili nic z obrzydliwych obyczajów, którymi się rządzono przed wami, abyście nie splugawili się przez nie. Ja jestem Pan, Bóg wasz! (Kpł 18,24-30).

W rozdziale 20 padną podobne słowa:

Będziecie strzec wszystkich moich ustaw i wszystkich moich wyroków i będziecie je wykonywać, aby was nie wypluła ziemia, do której was wprowadzam, abyście mieszkali w niej. Nie będziecie postępowali według obyczaju narodu, który wypędzam przed wami. Ponieważ wszystkie te rzeczy czynili, napełnili Mnie obrzydzeniem. Dlatego powiedziałem wam: wy posiądziecie ich ziemię, opływającą w mleko i miód. Ja jestem Pan, Bóg wasz, który was oddzieliłem od innych narodów (Kpł 20,22-24).

Zgodnie z taką interpretacją świętość Izraelitów ma być zatem większa niż innych narodów, które czyniły owe wykroczenia wyliczane pośród wykroczeń sfery seksualnej, a nazwane bardzo mocno „obrzydliwościami” (hebr. תiּn: Pobożny Izraelita musiał kategorycznie odrzucić tak określane czynności: ze względu na Boga

Wenham, The Book of Leviticus, 258-260. 
i - co ciekawe - ze względu na kraj, który Pan poprzysiągł dać Izraelitom. Jest w tym stwierdzeniu dość zawoalowana, ale wyraźna teologia ziemi (którą Samuel E. Balentine za J. Joostenem nazywa swoiście „spersonifikowaną ziemią” ${ }^{37}$ : Pan odebrał ową ziemię Kananejczykom (i innym narodom), gdyż ci uprawiali te „obrzydliwości”, zaś dał ją Izraelitom, którzy z tego powodu mają ich nie czynić3 ${ }^{38}$. Jeszcze późna Księga Ezdrasza powtórzy tę teologię: „Ziemia, w której posiadanie wchodzicie, jest ziemią

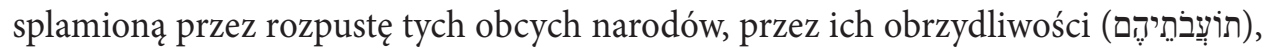
którymi ją w nieczystości swej napełnili od końca do końca" (Ezd 9,11). Dokument Papieskiej Komisji Biblijnej Naród żydowski i jego Święte Pisma w Biblii chrześcijańskiej (z 2002 r.) w punkcie 56 precyzuje: „Według tradycji kapłańskiej, kraj powinien być wolny od nieczystości, ponieważ zamieszkuje go sam Bóg (Lb 35,34). Dar [ziemi] uwarunkowany jest czystością moralną"39.

Można zadać pytanie, czy ponieważ taki argument i uzasadnienie samego tekstu biblijnego, odnoszącego się do czystości ziemi, dotyczy ze swej natury przeszłości i konkretnych uwarunkowań historycznych, przepisy te nie straciły na aktualności ${ }^{40}$ Autorzy niedawnego opracowania dotyczącego homoseksualizmu w Biblii stwierdzają: „This means, in effect, that a particular historical condition desired this interpretation. But this historical condition having disappeared, the prohibition itself has lost its raison dêtre” („W efekcie oznacza to, że taka interpretacja była podyktowana przez określone uwarunkowania historyczne. Ale gdy ten historyczny kontekst zniknął, sam zakaz stracił rację bytu") ${ }^{41}$.

Jak zatem można jeszcze uzasadnić ów zakaz wszelkich aktów homoseksualnych, nazwanych w wesetach 18,22 oraz 20,13 „obrzydliwością"? Istnieje kilka proponowanych interpretacji dawniejszych i współczesnych.

Po pierwsze, tradycyjne interpretacje zakazu czynów homoseksualnych wiążą się z tym, iż każda aktywność seksualna, zgodnie z przykazaniem płodności, powinna prowadzić do prokreacji, co w naturalny sposób zarezerwowane jest dla relacji kobiety i mężczyzny, a w co w relacji homoseksualnej (lub lesbijskiej) nigdy nie ma miejsca ${ }^{42}$. Seksualne relacje między mężczyznami prawodawca biblijny traktuje jako marnowanie męskiego nasienia ${ }^{43}$, co Prawo zauważa także w innych miejscach (np. o wylewaniu nasienia, por. np. cały kontekst Kpł 15, zwł. ww. 16-18, m.in. zakaz współżycia $\mathrm{z}$ kobietą $\mathrm{w}$ trakcie menstruacji, który zasadniczo, jak wierzył świat sta-

Zob. Balentine, Levitico, 188-189; por. Joosten, People and Land in the Holiness Code, 152-154.

Por. Hartley, Leviticus, 300-301; por. także: Milgrom, Leviticus 17-22, 1566-1567. Zob. także: Himbaza Schenker - Edart, The Bible on the Question of Homosexuality, 47-49.

Papieska Komisja Biblijna, Naród żydowski i jego Święte Pisma, 112.

Na temat (nie)aktualności tych przepisów na różnych poziomach zob. Sklar, „The Prohibitions Against Homosexual Sex", 165-198.

Himbaza - Schenker - Edart, The Bible on the Question of Homosexuality, 49.

Himbaza - Schenker - Edart, The Bible on the Question of Homosexuality, 49-50.

Por. np. Eilberg-Schwartz, The Savage in Judaism, 186; por. Milgrom, Leviticus 17-22, 1566. 
rożytny, jest dla kobiety okresem niepłodnym ${ }^{44}$ ). W takim kierunku szła interpretacja żydowska, np. w starożytności Filon Aleksandryjski ${ }^{45}$, a później Ramban ${ }^{46}$. Zakaz aktów homoseksualnych wiązałby się z wylewaniem męskiego nasienia „na próżno”, bez szans na poczęcie nowego życia, a przecież o to chodzi w darze seksualności udzielonym człowiekowi ${ }^{47}$ : przekazywanie życia jest jednym z pierwszych przykazań

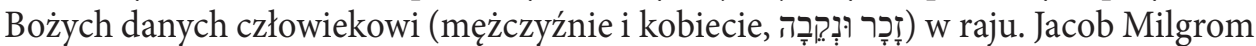
zastanawia się, czy remedium na takie niewypełnienie przykazania nie mogłoby być adoptowanie dzieci przez parę homoseksualną (wówczas posiadanie potomstwa usprawiedliwiałoby relacje homoseksualne), co jednak, jak sam stwierdza, nie było możliwą opcją w starożytności ${ }^{48}$. Trzeba jednak zauważyć, że nadal akt homoseksualny (nie związek) pozostawałby zakazany z innych względów, odnoszących się do kategorii czystości.

Po drugie, niektórzy komentatorzy zakaz praktyk homoseksualnych traktowali bardzo biologicznie, jako będący wynikiem zakazu niestosownego mieszania nasienia męskiego z innymi płynami nieczystymi, jak to ma miejsce w czasie seksu analnego (homoseksualnego) ${ }^{49}$. W takim wypadku przepis dotyczyłby tylko partnera aktywnego (bierny, przyjmujący nie byłby tu wspomniany ${ }^{50}$. Dopiero w kontekście penalizacji w Kpł 20,13 pojawia się klarowne objaśnienie, że winę za akty homoseksualne ponoszą „obaj”, co podkreśli hebrajski termin שִׁניהֶם (zob. dalej). Przepis odnosiłby się wówczas do nieczystości, a nieczystość wynikałaby z kontaktu z nieczystymi substancjami, a to z kolei - co ważne w kontekście Księgi Kapłańskiej - groziłoby nieczystością przedmiotów, domostwa, a zwłaszcza nieczystością w odniesieniu do kultu ${ }^{51}$. Taka interpretacja wykluczałaby także sugerowaną nieraz współcześnie interpretację tego prawa jako sprowadzoną do zakazu współżycia między mężczyznami w rodzinie - J. Milgrom w swoim komentarzu ukazuje, że w tych tekstach, które w całości kontekstu podejmują zakaz rozmaitych wykroczeń seksualnych w obrębie rodziny, w zakazie praktyk homoseksualnych może także chodzić jedynie o zakaz współżycia z innymi mężczyznami w rodzinie (a nie zakaz

44 Zob. Szerokie omówienie różnych interpretacji tego tekstu: Strzałkowska, Rozporządzenia dotyczące kobiet w Kpł 15, zwł. 165-167; por. także: Himbaza - Schenker - Edart, The Bible on the Question of Homosexuality, 49-50.

45 Milgrom, Leviticus 17-22, 1750.

46 Por. Milgrom, Leviticus 17-22, 1567.

47 Greenberg, Wrestling With God and Man, 93-95.

48 Milgrom, Leviticus 17-22, 1568-1569.

49 Bigger, „The Family Laws of Leviticus 18”, 188-203; Olyan, „And with a Male You Shall Not Lie”, 57-83; por. Milgrom, Leviticus 17-22, 1566.

50 Olyan, „And with a Male You Shall Not Lie”, 205; por. Milgrom, Leviticus 17-22, 1566. Na temat aktywnego i pasywnego partnera w interpretacji obu omawianych wersetów zob. także: Walsh, „Leviticus 18:22 and 20:13”, 201-209; Hollenback, „Who is Doing What to Whom Revisited”, 529-537.

51 Milgrom, Leviticus 17-22, 1567. Na temat nieczystości w kontekście seksualnym, zarówno w odniesieniu do kobiet, jak i mężczyzn, zob. analizę: Strzałkowska, Rozporządzenia dotyczace kobiet w Kpł 15, 57-148 (w odniesieniu do mężczyzn zwł. strony 61-67). 
homoseksualizmu w ogóle) $)^{52}$. Takiej interpretacji przeczy kategoria czystości, a także fakt, że zakazy rozdziału 18 dotyczą, obok członków rodziny, także np. współżycia z żoną bliźniego (cudzołóstwa; por. Kpł 18,20).

Po trzecie, w obu omawianych przepisach mogłoby chodzić o, jak to ujmują niektórzy współcześni autorzy, „zachowanie pokoju w szeroko rozumianej rodzinie i zagwarantowanie bezpieczeństwa każdemu z jej członków" ${ }^{53}$. Wszelkie relacje seksualne pozamałżeńskie (a takimi były relacje homoseksualne) mogły stwarzać zagrożenie dla rodziny jako podstawowej komórki społecznej. Przepisy z 18,22 i 20,13 wskazywałby na „niebezpieczeństwo pomieszania ról, które zagrażało harmonii relacji rodzinnych" ${ }^{34}$. A te, jak wiadomo, na Bliskim Wschodzie w starożytności były - i w tradycyjnych społecznościach nadal są - kluczowe dla budowania tożsamości indywidualnej.

Nieuporządkowane pragnienie seksualne stwarzało zawsze zagrożenie i potrzebowało nadania mu ram - to dlatego od początku narracja biblijna ukazuje seksualność jako dar, ale ogranicza swobodę w tym zakresie, obwarowując tę sferę życia szeregiem praw, przypisując poszczególne role, i w ten sposób także wyróżniając tę sferę egzystencji, której człowiek zawdzięcza przekazywanie nowego życia, nadając jej zarazem jakby „boski” charakter. Ze względu na rozmaite, dotąd wspomniane uwarunkowania, nie było w tym prawodawstwie ani w tradycji jego odczytywania miejsca na miłość homoseksualną, która nie realizuje się przecież w małżeństwie.

Po czwarte w końcu, chodziło o odróżnienie praktyk żydowskich od praktyk innych narodów ${ }^{55}$ (co już było wspomniane), ale zwłaszcza tych praktyk, które mogły kojarzyć się z prostytucją sakralną męską, praktykowaną wśród innych ludów Bliskiego Wschodu w starożytności, np. w Mezopotamii. A co z penalizacją czynów homoseksualnych wspomnianą w Kpł 20,13? Obok przypomnienia przepisu (w formie kazuistycznej) werset Kpł 20,13 dodaje do niego karę za jego niezachowanie. W tym wypadku karę najwyższą: karę śmierci. Kategoryczność kary podkreśla wagę zakazu: מוֹת יוּרָתוּ (dosł. „śmiercią umrą”; „na pewno winni umrzeć”) z dodaniem mocnego potwierdzenia wyrażającego przekonanie, które znamy z kart Nowego Testamentu

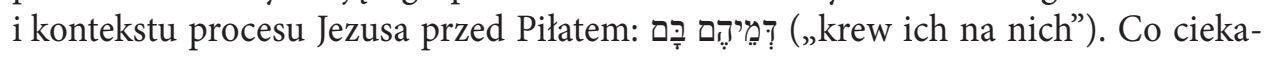
we, tego ostatniego wyrażenia nie tłumaczy LXX, która pozostawia jedynie pierwszą część tej kary, używając za to na jej oddanie dwóch czasowników, które zapewne skła-

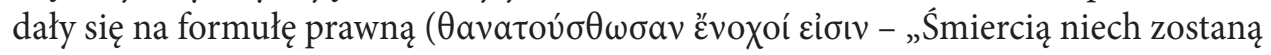
ukarani [imperativus]. Winni są”). Usunięcie formuły „krew ich na nich” być może

\footnotetext{
52 Milgrom, Leviticus 17-22, 1569.

53 Himbaza - Schenker - Edart, The Bible on the Question of Homosexuality, 50-52.

54 „The danger of a confusion of roles that threatens the harmony of familial relations" (Himbaza - Schenker - Edart, The Bible on the Question of Homosexuality, 50).

55 Por. Greenberg, Wrestling With God and Man, 90-92.
} 
miała na celu uniknięcie niezrozumienia: obyczaj grecki nie znał tego typu wyrażenia i mógłby być źle odebrany przez adrestów greckiego tekstu księgi.

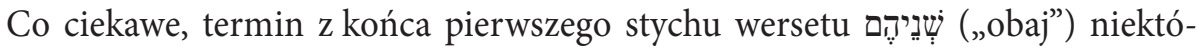
re współczesne przekłady (np. Biblia Tysiąclecia) przenoszą do drugiego stychu, co może być próbą harmonizacji tekstu; czyni tak także jedna starożytna wersja: Pięcioksiąg Samarytański, przenosząc ten termin nawet po hebrajskim wyrażeniu מוֹת יוּלָתו Jednak wersja taka jak w TM (i jak zaprezentowana powyżej) obecna jest we wszystkich pozostałych ważnych wersjach tekstu (LXX, Peš, Targ.), a także w rękopisie hebrajskim odnalezionym w Qumran: 4QRPe ${ }^{56}$. Użycie tego terminu pomaga także odpowiednio zinterpretować ten tekst, ukazując, iż obie strony aktu homoseksualnego (niezależnie od przyjętych ról - aktywnej i pasywnej), ponoszą odpowiedzialność za przekroczenie tego przykazania.

Dlaczego taka najwyższa kara, kara śmierci? Warto wspomnieć, że poza wersetem 20,21, kara śmierci dotyczy wszystkich zakazanych aktów sfery seksualnej (nie tylko aktów homoseksualnych, ale też kazirodczych wyliczanych w Kpł 20). Niektórzy wyjaśniają:

Jest prawdopodobne, że kara śmierci, najgorsza jaka istnieje, da się wyjaśnić przez fakt, że aż dwie osoby są zaangażowane w jej popełnienie, na co oboje [obaj/obie] wyrażają zgodę. Ta jednoznaczna zgoda jest dodatkową okolicznością obciążającą przy popełnieniu czynu zabronionego, ponieważ zostaje w niej przekroczony próg osobistego wstydu [ang. sha$\mathrm{me}{ }^{57} \mathrm{~W}$ celu pozyskania wspólnika potrzebnego do popełnienia owego czynu. W ten sposób wina jest podwójna: spowodowana samym aktem, a także kuszeniem prowadzącym do zepsucia kogoś innego ${ }^{58}$.

Najlepszym obrazem takiego grzechu popełnianego wspólnie jest grzech pierwszych rodziców, Adama i Ewy w raju (Rdz 3).

Jednocześnie, co ważne, gdy w prawodawstwie biblijnym czytamy o zasądzaniu kary śmierci, musimy mieć świadomość, że nigdzie tekst Biblii Hebrajskiej nie ukazuje jej wykonania za czyny ze sfery seksualnej. Być może wyliczenie takiej kary miało być środkiem ostrzegawczym przed popełnianiem tego typu czynów ${ }^{59}$. A być może takiej kary nie dało się nigdy zasądzić - można w tym kontekście przypomnieć jedynie, iż „złośliwi mówią, że do zasądzenia kary śmierci potrzeba było jeszcze dwóch świadków (poza zainteresowanymi), więc trudno w sytuacji intymnej o znalezienie takich właśnie” ${ }^{\prime 0}$. Co jeszcze ważniejsze, wina za takie ukryte wykroczenie

\footnotetext{
56 Himbaza (red.), ויקרא Leviticus, $113^{*}-114^{*}$.

57 Nie trzeba wspominać, że obok honoru (ang. honor) wstyd (ang. shame) stanowi ważną kategorię oceny czynów w kulturach i społecznościach Bliskiego Wschodu.

58 Himbaza - Schenker - Edart, The Bible on the Question of Homosexuality, 62.

59 Himbaza - Schenker - Edart, The Bible on the Question of Homosexuality, 63.

60 Strzałkowska, „Przemoc wobec kobiet”, 23.
} 
(którego nie można było zasądzić), według mentalności starożytnego Izraela, spadała niejako na całą społeczność. Może stąd taki radykalizm zapowiadanej kary ${ }^{61}$. Choć naturalnie problem stosowalności prawa biblijnego Izraela i jego egzekucji pozostaje otwarty.

\section{Współczesne propozycje interpretacji tekstów prawnych dotyczących homoseksualizmu}

W ostatnich latach pojawiło się wiele naukowych opracowań, próbujących ukazać treść biblijnego prawodawstwa inaczej niż zaprezentowane dotychczas interpretacje tradycyjne. Autorzy w bardzo różny sposób próbują debatować z prawodawstwem biblijnym w kwestii homoseksualizmu, ukazując je jako niebędące klarownie przeciwne relacjom homoseksualnym. Robią to na różnych płaszczyznach.

Pierwszą jest płaszczyzna hermeneutyczna, w której proponuje się inną od dosłownej lekturę tych tekstów prawodawstwa, odwołującą się przede wszystkim do wrażliwości samego czytelnika i do jego własnej percepcji tekstu.

Propozycję taką wysunął np. Gérald Caron ${ }^{62}$. W swoim artykule (drugim z serii czterech na temat homoseksualizmu i słowa Bożego) kwestionuje on znaczenie i zakres podwójnego zakazu z Księgi Kapłańskiej w obecnej debacie na temat homoseksualizmu. Choć oba omówione teksty wydają się jednoznacznie potępiać seks między mężczyznami, to jak zauważa autor, obecnie powszechnie uznaje się, że zakaz ten nie odnosi się do homoseksualizmu we współczesnym tego słowa znaczeniu, a w związku z tym debata na temat interpretacji tekstu w dzisiejszym kontekście pozostaje otwarta. W pierwszej części artykułu autor omawia kwestie egzegetyczne, natomiast druga - kluczowa - dotyczy strony ściśle hermeneutycznej. Autor proponuje nowe podejście do autorytetu Biblii, które w procesie interpretacji tekstu biblijnego pozwala rozpoznać ważną rolę dzisiejszego czytelnika.

Takie nowe podejście hermeneutyczne jest zresztą charakterystyczne dla większości publikacji ostatnich lat, omawiających temat homoseksualności, co jest wartościowe samo w sobie, niemniej prowadzi czasem do niesłusznego wniosku, iż tekst biblijny jest niejednoznaczny w swoim prawodawstwie lub że należy go dostosować do współczesnego odbiorcy ${ }^{63}$. Na przykład J. Töyräänvuori zauważa, że „,homoseksualizm w dzisiejszym rozumieniu nie istniał w starożytnym świecie, stąd prawodawstwa nie mogą odnosić się do równej, kochającej i zmysłowej relacji między dwoma

\footnotetext{
61 Himbaza - Schenker - Edart, The Bible on the Question of Homosexuality, 64.

62 Caron, „Le Lévitique condamnerait-il l'homosexualité?”, 27-49.

63 Por. Sklar, „The Prohibitions Against Homosexual Sex”, 165-198
} 
dorosłymi mężczyznami” ${ }^{4}$. Jan Joosten dodaje: „werset $[18,22]$ nie odnosi się w ogóle do tego, co motywowało stosunek: atrakcyjność męsko-męska, pragnienie upokorzenia, nieodparta żądza czy też inne czynniki. Nawet kwestia zgody partnera pozostaje niewymieniona. Tekst w sposób zdecydowany skupia się na akcie seksualnym"65.

Zdaniem wielu współczesnych badaczy to konkretne prawo odnoszące się do aktów homoseksualnych nie przystaje do dzisiejszego człowieka - również wierzącego - który na kwestie homoseksualności patrzy inaczej, z większą otwartością ${ }^{66}$. $\mathrm{Z}$ takiego powodu próbuje się często dostosować tekst biblijny do potrzeb owego czytelnika.

Takie podejście może nieść niebezpieczeństwo cenzurowania tekstu biblijnego i dostosowywania go do pojawiających się potrzeb. Jeśli przyjmiemy faktycznie taki nowy klucz hermeneutyczny, wówczas wiele z tego, o czym mówi Biblia i Tradycja (bo nie chodzi przecież o sam tekst biblijny, ale również o jego wielowiekową interpretację we wspólnotach żydowskich i chrześcijańskich), można podważyć. O wiele lepiej jest chyba stwierdzić, że w czasach biblijnych oceniano homoseksualizm bardzo negatywnie (i co do interpretacji tekstu biblijnego w starożytności nie ma wątpliwości), ale jednocześnie warto zauważyć, że czym innym jest jego aktualność dziś. Jay Sklar w swoim niedawnym opracowaniu ${ }^{67}$ wylicza kilka poziomów, na których omawiane przepisy, dotyczące homoseksualizmu, mogą pozostać aktualne bądź się zdezaktualizować. Po pierwsze są nieaktualne, bo w ogóle prawodawstwo Księgi Kapłańskiej jest już nieaktualne. ${ }^{68}$ Po drugie, zakazy nie mają zastosowania dzisiaj, ponieważ powód, dla którego ta czynność była zabroniona w Księdze Kapłańskiej (czystość rytualna i odniesienie do kultu), nie jest już dzisiaj obowiązujący ${ }^{69}$. Jednocześnie autor, dokonując ważnego rozróżnienia między czystością rytualną a czystością moralną, proponuje, by zwrócić uwagę na fakt, że w NT przepisy dotyczące sfery seksualnej są wymieniane jako nadal obowiązujące (np. w listach św. Pawła), a zatem dotyczą czegoś więcej niż tylko kultu i czystości rytualnej. Dotyczą - zdaniem badacza - czystości moralnej, która pozostaje aktualna. Zarazem są także związane z nakazem płodności z Księgi Rodzaju, a owa płodność dokonuje się tylko w relacjach kobiety i mężczyzny. Stąd wniosek autora, że omawiane prawa powinny być traktowane jako wciąż aktualne, w przeciwieństwie do innych czysto kultycznych przepisów Księgi Kapłańskiej, które straciły swą aktualność ${ }^{70}$.

64 „Homosexuality, as we understand it today, did not exist in the ancient world, and hence the statutes cannot have referred to an equal, loving, and sensual relationship between two adult males” (Töyräänvuori, „Homosexuality”, 238).

65 Joosten, „A New Interpretation of Leviticus 18:22”, 3.

66 Por. Römer, „Homosexualität und die Bibel”, 47-63.

67 Por. Sklar, „The Prohibitions Against Homosexual Sex”, 165-198.

68 Por. Sklar, „The Prohibitions Against Homosexual Sex”, 168-173.

69 Por. Sklar, „The Prohibitions Against Homosexual Sex”, 173-187.

70 Por. Sklar, „The Prohibitions Against Homosexual Sex”, 189-195. 
Kwestia aktualności Księgi Kapłańskiej i jej przepisów była podejmowana od pierwszych wieków chrześcijaństwa: Orygenes na przełomie II i III w. po Chr. zastanawiał się już, jak zachęcić chrześcijan do lektury Księgi Kapłańskiej, która przez wielu już wówczas uważana była za nieaktualną po wydarzeniu i dziele Jezusa Chrystusa, ukazując jej wagę w serii homilii do Księgi Kapłańskiej, pisanych w czasach, gdy zmieniły się ramy religijności judaistycznej (zwłaszcza brak Świątyni jerozolimskij po 70 r. po Chr.) i chrześcijaństwa. Również w późniejszych latach odnoszono się do prawodawstwa biblijnego Izraela, ukazując z jednej strony jego wartość historyczną (dla poznania czasów biblijnych), a z drugiej także aktualizację konkretnych przepisów (nawet tych, które, choćby ze względu na brak Świątyni jerozolimskiej, straciły na aktualności) i ich aplikację w konkretnej wspólnocie. Do kwestii aktualności przepisów prawnych zawartych w Torze i ich chrześcijańskiej interpretacji odnosi się wspomniany dokument Papieskiej Komisji Biblijnej Naród żydowski i jego Święte Pisma w Biblii chrześcijańskiej (2002). W punkcie 43 czytamy:

Z punktu widzenia historycznego prawa biblijne są wynikiem długiej historii tradycji religijnych moralnych i prawnych. Zawierają one liczne elementy wspólne z cywilizacją starożytnego Bliskiego Wschodu [...]. Jest ono partykularne, dostosowane do konkretnego historycznego narodu. Jednak ma ono wartość przykładową dla całej ludzkości (Pwt 4,6). [...] Ucieleśnia religijną antropologię i zespół wartości, które wychodzą poza naród i warunki historyczne, jakich prawa biblijne są po części wytworem ${ }^{71}$.

Zawsze należy pamiętać, iż interpretując tekst biblijny, w tym przypadku prawny, odnosimy się nie tylko do litery Prawa, ale także do tradycji jego odczytywania, a ta w przypadku homoseksualizmu do końca XX w. pozostawała niezmienna i nie podawana w wątpliwość. Tak nadal czyni zresztą tradycja katolicka, co potwierdza najnowsza nota Kongregacji Doktryny Wiary z 22 lutego 2021 r., zakazująca błogosławienia par homoseksualnych w Kościele katolickim ${ }^{72}$.

Niektóre współczesne interpretacje przepisów dotyczących homoseksualizmu odnoszą się do ich kontekstu historycznego (i wartości historycznej wyłącznie). Część badaczy próbuje wykazać, że te konkretne teksty prawne należy interpretować jedynie w ich kontekście historycznym. Martin Leuenberger, analizując Rdz 1,27 oraz Kpł 18,22 i 20,13 ukazuje, że przepisy regulujące kwestie homoseksualizmu i faktycznie go zakazujące miały swoje konkretne uwarunkowania historyczne (a nie powinny być traktowane jako zasada ogólna). Miały służyć zapewnieniu przetrwa-

71 Papieska Komisja Biblijna, Naród żydowski i jego Święte Pisma, 86-87. Por. także punkt 87 dokumentu (strony 172-174).

72 Zob. Kongregacja Nauki Wiary, Uwagi dotyczace projektów legalizacji związków między osobami homoseksualnymi. 
nia pokoleniom narodu biblijnego Izraela w kontekście powygnaniowym, perskim, gdy naród takiego przetrwania potrzebowa ${ }^{73}$. Stąd mocny akcent położony na zakaz relacji homoseksualnych i podkreślenie istotności relacji dwupłciowych, zapewniających przetrwanie pokoleniom Izraela. Wpływy perskie na prawodawstwo biblijnego Izraela w tym, co dotyczy homoseksualizmu dostrzega także Idan Dershowitz ${ }^{74}$, który zarazem ukazuje, że prawo z Kpł 18,22 zabrania kazirodczych stosunków homoseksualnych (a nie stosunków homoseksualnych w ogóle) ${ }^{75}$.

Obok klucza hermeneutycznego i historycznego, ukazujących nieaktualność przepisów ST lub dostosowujących je do potrzeb współczesnego czytelnika, w niektórych badaniach współczesnych podejmuje się próby nowego odczytania samej treści przepisów Kpł 18,22 i 20,13. Wielu - niejednokrotnie wbrew tradycji interpretacji i gramatyce obu omówionych tekstów - stara się ukazać, że nie są one jasne i jednoznaczne. Na przykład Saul M Olyan zauważa w swoim tekście z 2011 r. (choć jego pierwsza wersja ukazała się w $1994 \mathrm{r}^{76}$ ), że: 1) prawodawstwo zawarte w Kpł 18,22 oraz 20,13 nie jest aż tak jasne na pierwszy rzut oka i w gruncie rzeczy nie wiadomo, o jaki dokładnie czyn bądź czyny seksualne z udziałem mężczyzn miałoby w nich chodzićc ${ }^{77} ; 2$ ) być może należy interpretować je jako zakaz wymuszonego seksu między mężczyznami (inaczej gwałtu) ${ }^{78}$; 3 ) używany przez tekst hebrajski obu wersetów

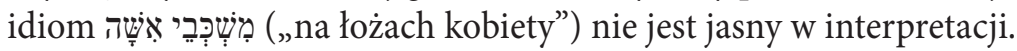

Idąca dokładnie tą samą ścieżką rozważań na temat tego wyrażenia J. Töyräänvuori próbowała w 2020 r. udowodnić, że w obu tekstach chodzi o to, by mężczyzna nie kładł się na łożu kobiety jednocześnie z innym mężczyzną ${ }^{79}$, co wykluczałoby interpretację zakazu jako odniesionego do aktu homoseksualnego. Zdaniem badaczki w obu wspomnianych wersetach Księgi Kapłańskiej w ogóle nie chodzi o relacje homoseksualne, a o leżenie (sypianie, czyli współżycie) z kobietą. Zaś J. Joosten, interpretując to samo wyrażenie, formułuje wniosek, że w tekście tym chodzi wyłącznie o współżycie z żonatym mężczyzną (a nie mężczyzną w ogóle) ${ }^{80}$.

Warto zauważyć, że wszystkie te interpretacje negują wielowiekową tradycję lektury tych tekstów, ignorując najstarsze jego wersje, tłumaczenia, komentarze. Co jeszcze bardziej zaskakujące, współczesne interpretacje owo wyrażenie idiomatyczne, co do znaczenia którego nie miały wątpliwości poprzednie pokolenia badaczy i tłumaczy żydowskich i chrześcijańskich, wydają się interpretować zbyt dosłownie.

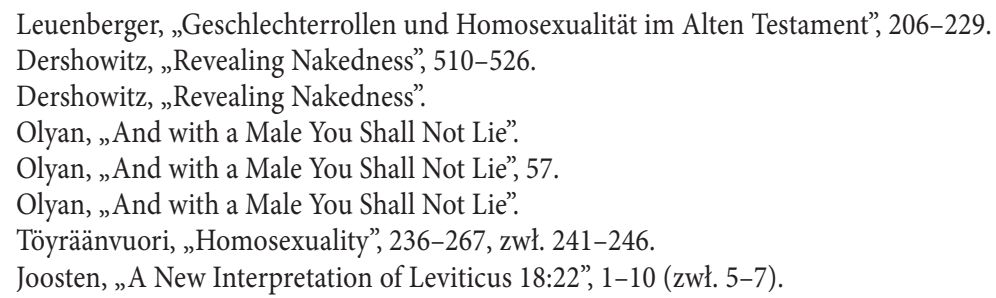


Paradoksem w tym kontekście wydaje się konkluzja wspomnianego artykułu, w którym J. Töyräänvuori sama pisze, iż „jest kluczowym, by badacz tekstu starożytnego jak najmniej wkładał do interpretacji tekstu starożytnego swoich własnych z góry przyjętych pojęć i kontekstów, albo przynajmniej miał świadomość swych własnych uprzedzeń dotyczących interpretacji tekstów i tego, jak mogą one wpłynąć na ich odczytywanie"s1.

\section{Męska prostytucja sakralna? Pwt 23,18-19 oraz Kpł 18,21(?)}

Nawiązania do relacji homoseksualnych w prawodawstwie Tory można zauważyć jeszcze w dwóch miejscach - w Pwt 23,18-19, gdzie jest mowa o męskiej prostytucji sakralnej, oraz w niejasnym w swoim znaczeniu tekście z Kpł 18,21.

Męska prostytucja sakralna była bez wątpienia praktykowana wśród ludów ościennych (np. w Mezopotamii) ${ }^{82}$, a biblijni Izraelici mieli jej unikać - zresztą tak jak wszystkiego, co oferowały obce kulty. Jednak oba wspomniane teksty wzbudzają wiele debat wśród badaczy co do ich interpretacji ${ }^{83}$.

Pierwszy z tekstów, Pwt 28,18-19, w TM brzmi:

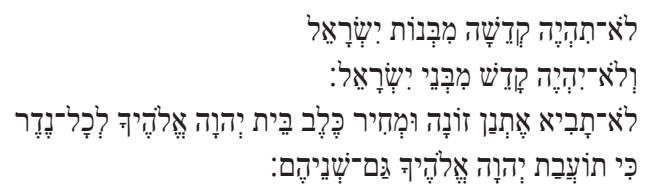

Nie będzie prostytutki sakralnej (hebr. הְִ̣̣) pośród córek Izraela

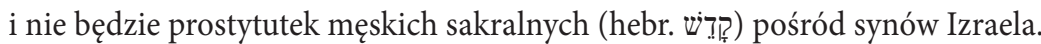

Nie przyniesiesz zarobku nierządnicy (hebr. זٓ⿱זְָ) ani zapłaty psa (hebr.

do Domu Pana, Boga twego, jako ofiarę ślubowania.

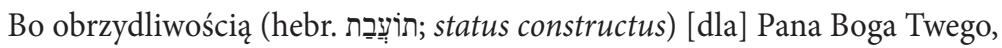

[są] także obie [te rzeczy].

81 „It is therefore crucial that a scholar of ancient texts insert as little as possible of his or her own preconceived notions and contexts into the interpretation of ancient texts, or at the very least be aware of his or her own biases concerning the interpretation of texts and how one's readings may be impacted by them" (Töyräänvuori, „Homosexuality”, 264).

82 Na temat prostytucji (także męskiej) w świecie starożytnym zob. Faraone - McClure (red.), Prostitutes and Courtesans. O Mezopotamii zob. np. Goodnick Westenholz, „Heilige Hochzeit und kultische Prostitution", 43-62.

83 Na temat męskiej prostytucji sakralnej zob.: Bird, „The End of the Male Cult Prostitute”, 37-80; Day, "Does the Old Testament Refer to Sacred Prostitution", 2-21; Stark, "Kultprostitution" im Alten Testament?; Slawik, „Czy w starożytnym Izraelu istniała prostytucja sakralna?”, 45-65; Lemański, „Zapłata psa”, 49-64; Jodzio, „Zjawisko prostytucji w Starym Testamencie”, 317-343. 
Fragment ten należy do zbioru regulacji o różnym charakterze, zarówno kultycznym, jak i społecznym. Bezpośrednio poprzedza go zakaz wydawania zbiegłego niewolnika w ręce jego pana i zakaz uciskania go (Pwt 23,16-17), a po omawianych wersetach następuje zakaz pobierania odsetek od bliźniego $(23,20-21)^{84}$. Wszystkie zatem przepisy tej części Księgi Powtórzonego Prawa dotyczą różnych sfer życia i wydają się ze sobą niepowiązane, choć jednocześnie sąsiadujące z Pwt 23,18-19 przepisy są dwuwersetowe. W gruncie rzeczy zasadniczy spór w interpretacji Pwt 23,18-19 dotyczy dwóch tematów: tego, czy wersety 18 i 19 należy odczytywać łącznie (dwa

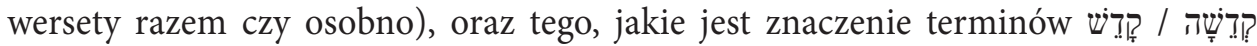
w wersecie 18.

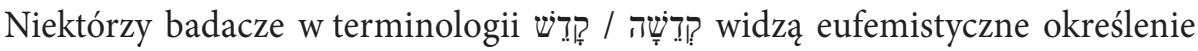
prostytucji sakralnej żeńskiej/męskiej, inni uważają, że chodzi w niej o inne funkcje świątynne, pełnione zarówno przez mężczyzn, jak i kobiety ${ }^{85}$. Ta pierwsza interpretacja jest możliwa zwłaszcza wtedy, gdy połączy się wersety 18 i 19. Wówczas werset 18 interpretować należy w kontekście wersetu 19, a ten wspomina o „zapłacie

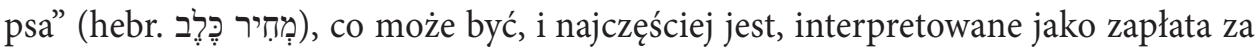
prostytucję sakralną męską, prostytucję homoseksualną (ocenioną bardzo negatywnie, skoro nazywa się ją „zapłatą psa”). Na prostytucję sakralną w wersecie 19 może wskazywać także uzasadnienie - prostytucja jest tam nazwana „obrzydliwością

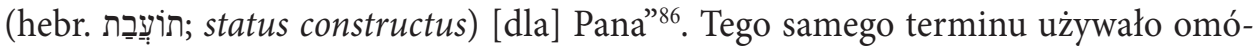
wione wcześniej prawodawstwo z Księgi Kapłańskiej, odnoszące się do homoseksualizmu. Jeśli werset 19 mówi o prostytucji homoseksualnej, wówczas połączony z nim werset 18 można by interpretować w ten sam sposób.

Niemniej jednak zarówno słownictwo, jak i gramatyka wskazują na to, że oba wersety należy traktować osobno. Nie można nie zauważyć, że zakazy wersetów 18 i 19 są zbudowane odmiennie: werset 18 to pozbawiony sankcji zakaz sformułowany w 3 os. l. poj., zaś 19 sformułowany jest w 2 os. l. poj. rodzaju męskiego i dotyczy bez wątpienia zapłaty za prostytucję żeńską i ową tajemniczą „zapłatę psa”" ${ }^{87}$. Jak zauważa Halina Jodzio: „nie możemy traktować terminów qedēšāh i qāaēš (w. 18) jako synonimów zônāh i 'zapłaty psa' (w. 19), dlatego terminu qee ēšāh nie należy tłumaczyć 'jako prostytutka sakralna', a qādēš jako jej męskiego odpowiednika. Chodzi tu raczej

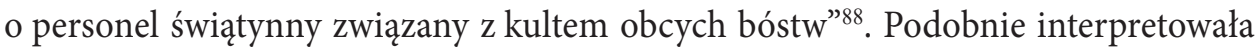
to Phyllis A. Bird ${ }^{89}$.

\footnotetext{
84 Por. Slawik, „Czy w starożytnym Izraelu istniała prostytucja sakralna?”, 57; Jodzio, „Zjawisko prostytucji w Starym Testamencie", 323.

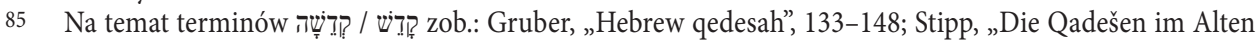
Testament”, 209-240; por. także: Bird, „The End of the Male Cult Prostitute”, 37-80

86 Por. Jodzio, „Zjawisko prostytucji w Starym Testamencie”, 323.

87 Por. Jodzio, „Zjawisko prostytucji w Starym Testamencie”, 323.

88 Jodzio, „Zjawisko prostytucji w Starym Testamencie”, 324.

89 Bird, „The End of the Male Cult Prostitute”, 37-80.
} 
Jednocześnie w wersecie 19 wyraźnie potępia się przynoszenie do Świątyni dochodów uzyskanych z prostytucji. O ile użyte słownictwo dotyczące zapłaty nierządnicy (hebr. זٓ⿱זְָ) nie pozostawia wątpliwości, iż chodzi o dochód z prostytucji (kobiet), o tyle największy problem przynosi interpretacja dosadnego wyrażenia „za-

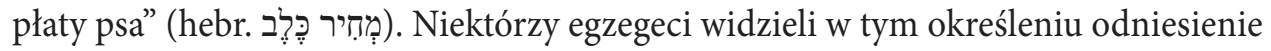
do pieniędzy uzyskanych ze sprzedaży psa (pomijając fakt, że użyte tu wyrażenie jest idiomatyczne i nie należy go odczytywać dosłownie $)^{90}$. Bardziej przekonująca wydaje się jednak interpretacja odnosząca to wyrażenie do wspomnianej zapłaty za stosunek homoseksualny ${ }^{91}$. Jak zauważa Janusz Lemański, przepis ten zwyczajowo rozumie się ,jako określenie mężczyzn uprawiających nierząd sakralny z innymi mężczyznami”" robku uzyskanego uprawianiem homoseksualnej, męskiej prostytucji w kontekście sakralnym”93. Halina Jodzio dodaje jeszcze: „Uzasadnieniem tego zakazu jest stwierdzenie, że obydwie te rzeczy (zapłata prostytutki i zapłata psa) są 'obrzydliwością dla JHWH'. Użyte tu słowo tô 'ēbāh odnosi się do osób, rzeczy bądź praktyk, które obrażają czyjś moralny lub rytualny porządek" 94 .

Ostrość użytych słów („zapłata psa”, „obrzydliwość”) zdają się także wskazywać na możliwy kontekst relacji homoseksualnych nierządnych jako złych, przede wszystkim z powodu tego, iż kojarzyły się z obcymi kultami, od których Izrael miał się radykalnie odcinać.

O ile zatem werset 18 - jak się wydaje - odnosi się do „kwalifikowanego personelu świątynnego" ${ }^{95}$ i nie mówi o prostytucji (wskazuje na to między innymi terminologia), o tyle werset 19 (odrębny od 18 gramatycznie i terminologicznie), dosadnie odnosi się do dochodów z prostytucji - kobiet i mężczyzn.

Jednocześnie, jak zauważa J. Lemański, czasem w Starym Testamencie nierząd i prostytucja określa jedynie „ogólne bałwochwalcze praktyki niezgodne z kultem JHWH w Izraelu"96. Bardzo trudno zatem jednoznacznie stwierdzić, czy w tekście zakazane są relacje homoseksualne w ramach prostytucji sakralnej, czy niegodna jest jedynie zapłata za nie, i czy w ogóle w tym tekście chodzi o prostytucję i składanie w Świątyni pieniędzy pochodzących z takiej ewentualnie aktywności.

Jeszcze mniej jasnym wersetem w omawianym kontekście jest Kpł 18,21. W TM brzmi on:

\footnotetext{
90 Slawik, „Czy w starożytnym Izraelu istniała prostytucja sakralna?”, 59, por. także: Jodzio, „Zjawisko prostytucji w Starym Testamencie”, 324.

91 Por. Jodzio, „Zjawisko prostytucji w Starym Testamencie”, 324; por. także: Lemański, „Zapłata psa”, 49-64 (zw1. 56-62).

92 Lemański, „Negatywny obraz psa w Biblii”, 86.

93 Lemański, „Negatywny obraz psa w Biblii”, 86.

94 Jodzio, „Zjawisko prostytucji w Starym Testamencie”, 324.

95 Por. Lemański, „Negatywny obraz psa w Biblii”, 86.

96 Por. Lemański, „Negatywny obraz psa w Biblii”, 87.
} 
A ze swego potomstwa (także „nasienia”; hebr. זָּ) nie oddasz, aby przeszło przez ogień dla Moleka, I nie będziesz profanował Imienia Twego Boga. Ja jestem Pan.

Werset ten na pierwszy rzut oka nie mówi o relacjach homoseksualnych, i jako jedyny w całym kontekście rozdziału 18 (który w całości poświęcony jest rozmaitym zakazom intymnej sfery życia) w ogóle nie nawiązuje, jak się wydaje, do sfery sek-

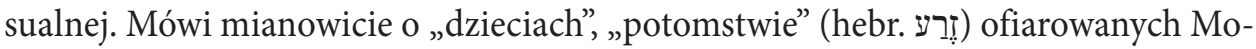
lekowi (pogańskiemu bóstwu), co naturalnie było klarownie zakazane przez Prawo. Ponieważ jednak w całym rozdziale mowa jest o zakazanej aktywności sfery seksualnej, a poprzednio omówione prawo zarazem dotyczyło kontekstu kultycznego, zaczęto rozważać, czy podobnie i tego wersetu nie należałoby zinterpretować w kluczu aktywności seksualnej w kontekście kultycznym, a konkretnie męskiej prostytucji sakralnej. Taką interpretację wysunął J.M. Sprinkle ${ }^{97}$. Oparł ją na znaczeniu hebrajskiego terminu זִּע który oprócz „potomstwa”, „dzieci”, może oznaczać bardziej dosłownie „męskie nasienie”. Przepis ten mógłby w takim rozumieniu wyrażać zakaz oddawania męskiego nasienia Molekowi - w rycie sakralnym, w obcym kulcie. Taka interpretacja pozostaje jednak bardzo problematyczna: nawet jeśli takie ofiarowanie nasienia (nie dzieci) następowałoby w kontekście kultycznym bożka Moleka, wcale nie oznacza to, iż dokonywałoby się ono w kontekście homoseksualnym czy prostytucji sakralnej męskiej. Taka interpretacja tekstu z Kpł 18,21 pozostaje zatem mało prawdopodobna, tym bardziej że, jak zauważa J. Milgrom, rozdział 20 penalizację tego samego zakazu związanego z Molekiem umieszcza w innej kolejności i oddzielnie od nadużyć sfery seksualnej ${ }^{98}$. I chociaż często, o czym mówi Milgrom, kananejskie „aberracje sfery seksualnej” mogły jednocześnie kojarzyć się z takimi w sferze kultycznej ${ }^{99}$, to jednak ten tekst nie wydaje się dobrym przykładem klarownego prawodawstwa związanego z aktami homoseksualnymi. Wydaje się zatem, że tekst ten nie odnosi się w ogóle do sfery seksualnej ${ }^{100}$.

Warto zauważyć także, że omówione przepisy, potencjalnie odnoszące się do męskiej prostytucji sakralnej, nie wynikają z potępienia samego aktu homoseksualnego, ale nade wszystko z kontekstu kultycznego, który w tym wypadku jest ważniejszy niż sam akt (do którego z kolei odnosiły się omówione wcześniej przepisy z Kpł 18,22 oraz 20,13).

\footnotetext{
97 Sprinkle, „Sexuality”, 751.

98 Milgrom, Leviticus 17-22, 1551-1552.

99 Milgrom, Leviticus 17-22, 1551.

100 Na jego temat zob. Milgrom, Leviticus 17-22, 1586-1591.
} 


\section{Zakończenie}

Prawodawstwo biblijnego Izraela w tym, co dotyczy homoseksualizmu wydaje się jednoznaczne: „Biblia nie pozwala ujmować homoseksualizmu w kategoriach choroby czy alternatywnej opcji życia płciowego. Jest to wyraźnie wykroczenie przeciw prawu Bożemu, jednoznacznie potępione w etyce zarówno żydowskiej, jak i chrześcijańskiej”101. Oczywiste jest także, że Biblia nigdzie nie zachęca do tego typu relacji, upatrując właściwej realizacji życia seksualnego w małżeństwie między kobietą a mężczyzną.

Warto przyjrzeć się w tym kontekście dokumentowi Papieskiej Komisji Biblijnej Czym jest człowiek? z 2019 r. ${ }^{102}$, w którym słusznie stwierdza, że w biblijnych tradycjach narracyjnych nie ma odniesienia do praktyk homoseksualnych, ani jako zachowania, za które należy winić, ani jako postaw tolerowanych lub zalecanych (nr 188). Jednocześnie trzeba jednak dodać, że w przypadku prawodawstwa (w odróżnieniu od tekstów narracyjnych), ocena aktów homoseksualnych jest w Biblii jednoznaczna i wyraźnie negatywna, a nawet penalizowana karą śmierci.

W każdym przypadku prawodawstwo klarownie potępia akty homoseksualne, oceniając je w kluczu świętości, odniesienia do Boga i kultu, w kluczu wartości relacji rodzinnych, a zarazem w odniesieniu do teologii ziemi: chcąc, by Izraelici pod względem rygoryzmu sfery seksualnej odróżniali się od innych narodów, wśród których takie praktyki mogły mieć miejsce.

Jednocześnie niektórzy współcześni badacze próbują wysnuć wniosek, że sam homoseksualizm nie został w Biblii tak mocno potępiony, jak się wydaje. Na przykładzie tego prawodawstwa można doskonale zobaczyć, jak podejmowane studia Pisma Świętego zmieniają się wraz z nowymi uwarunkowaniami. O ile podejmowanie częściej jakiejś tematyki jest słuszne i uprawnione, o tyle nie jest uprawnione używanie i nadużywanie tekstu Biblii jako argumentu do debaty społecznej w kwestii homoseksualizmu (dotyczy to każdej ze stron) lub odczytywanie biblijnego tekstu ideologicznie, w oderwaniu od realiów jej powstania. Refleksja naukowa, która zazwyczaj powinna poprzedzać inne bardziej popularne refleksje, w tym wypadku bywa, że staje się raczej próbą odpowiedzi na postulaty niektórych środowisk współczesnych, nadając prawodawczym tekstom biblijnym nową interpretację, która często o wiele więcej mówi o dzisiejszych badaczach niż o samym tekście biblijnym i praktyce społeczności starożytnej, która go tworzyła. Trzeba jasno powiedzieć, że w perspektywie prawodawstwa biblijnego Izraela i w jego kontekście jakakolwiek praktyka homoseksualna została jasno potępiona. Klarownie widać, że nie da się zmienić tekstu Biblii dostosowując go do współczesnego człowieka i jego pragnień. Tak zresztą przez wieki interpretowała ten tekst zarówno wspólnota żydowska, jak i chrześcijańska.

101 Tronina, Księga Kapłańska, 274.

102 Papieska Komisja Biblijna, Czym jest człowiek? 
W gruncie rzeczy cała ta dyskusja sprowadza się do tego, jak traktujemy Biblię: czy jest ona punktem wyjścia do dalszych rozważań, luźno z jej treścią związanych, czy punktem odniesienia, który należy rozwijać, zgłębiać i brać pod uwagę, bo ma kluczowe znaczenie dla naszego życia.

\section{Bibliografia}

Bahnsen, G.L., Homosexuality. A Biblical View (Grand Rapids, MI: Baker 1978).

Balch, D.L. (red.), Homosexuality, Science, and the "Plain Sense" of Scripture (Cambridge Grand Rapids, MI: Eerdmans 2000).

Balentine, S.E., Levitico (red. wyd. włoskiego C. Versino) (Strumenti Commentari 44; Torino: Claudiana 2008).

Becker, J., „Zum Problem der Homosexualität in der Bibel”, Zeitschrift für Evangelische Ethik 31/1 (1987) 36-59.

Bigger, S.F., „The Family Laws of Leviticus 18 in Their Setting”, Journal for Biblical Literature 98 (1979) 187-203.

Bird, Ph.A., „The End of the Male Cult Prostitute: A Literary-Historical and Sociological Analysis of Hebrew Qādēš-Qědēšîm”, Congress Volume Cambridge 1995 (red. J.A. Emerton) (Leiden: Brill 1997) 37-80.

Brawley, R.L. (red.), Biblical Ethics and Homosexuality. Listening to Scripture (Louisville, KY: Westminster John Knox Press 1996).

Caron, G., „Le Lévitique condamnerait-il l'homosexualité?: de l'exégèse à l'herméneutique”, Studies in Religion/Sciences Religieuses 38/1 (2009) 27-49.

Clements, R.E., "כָזָָ", Theological Dictionary of the Old Testament (red. G.J. Botterweck H. Ringrgren) (Grand Rapids, MI: Eerdmans 1980) IV, 82-87.

Day, J., „Does the Old Testament Refer to Sacred Prostitution and Did It Actually Exist in Ancient Israel?", Biblical and Near Eastern Essays (red. C. McCarthy) (London: Clark 2004) 2-21.

Dershowitz, I., „Revealing Nakedness and Concealing Homosexual Intercourse: Legal and Lexical Evolution in Leviticus 18", Hebrew Bible and Ancient Israel 6/4 (2017) 510-526.

Dershowitz, I., „Response to: «Was there ever an implicit acceptance of male homosexual Intercouse in Leviticus 18?» by George M. Hollenback in ZAW 131/3 (2019), 464-466”, Zeitschrift für die alttestamentliche Wissenschaft 131/4 (2019) 625-628.

Eilberg-Schwartz, H., The Savage in Judaism (Bloomington, IN: Indiana University Press 1990). Faraone, Ch.A. - McClure, L.K. (red.), Prostitutes and Courtesans in the Ancient World (Madison, WI: University of Wisconsin Press 2006.

Gagnon, R.A.J., The Bible and Homosexual Practice. Texts and Hermeneutics (Nashville, TN: Abingdon Press 2001).

Gagnon, R.A.J., - Via, D.O., Homosexuality in the Bible. Two Views (Minneapolis, MN: Fortress Press 2003).

Gilbert, M., „La Bible et l'homosexualité”, Nouvelle Revue Théologique 109 (1987) 78-95. 


\section{BARBARA STRZAŁKOWSKA}

Goodnick Westenholz, J., „Heilige Hochzeit und kultische Prostitution im Alten Mesopotamien", Wort und Dienst 23 (1995) 43-62.

Greenberg, S., Wrestling With God and Man. Homosexuality in the Jewish Tradition (Madison, WI: University of Wisconsin Press 2004).

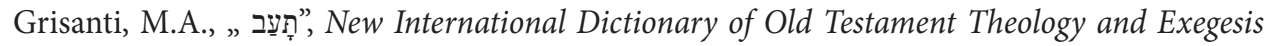
(red. W.A. VanGemeren) (Carlisle, U.K.: Paternoster 1996) IV, 314-318.

Gruber, M., „Hebrew qedesah and Her Canaanite and Akkadian Cognates”, Ugarit-Forschungen 18 (1986) 133-148.

Hamilton, V.P., „זָזָָ", New International Dictionary of Old Testament Theology and Exegesis (red. W.A. VanGemeren) (Carlisle U.K.: Paternoster 1996) I, 1106-1108.

Hartley, J.E., Leviticus (Word Biblical Commentary 4; Nashville, TN: Nelson 1992).

Helminiak, D.A., What the Bible Really Says About Homosexuality? Recent Findings by Top Scholars Offer a Radical New View (Tajique, NM: Alamo Square Press 2000).

Hieke, T., „Kennt und verurteilt das Alte Testament Homosexualität?, “Wer bin ich, ihn zu verurteilen?” Homosexualität und katholische Kirche (red. S. Goertz) (Freiburg: Herder 2015) $19-52$.

Himbaza, I. - Schenker, A. - Edart, J.-B., The Bible on the Question of Homosexuality (tł. B.M. Guevin) (Washington, D.C.: Catholic University of America Press 2012) (oryginał francuski: Clarifications sur l'homosexualité dans la Bible [Lire la Bible 147; Paris: Cerf 2007]).

Himbaza, I. (red.), Biblia Hebraica Quinta. III. ויקרא Leviticus (Stuttgart: Deustsche Bibelgesellschaft 2020).

Hollenback, G.M., „Who is Doing What to Whom Revisited: Another Look at Leviticus 18,22 and 20,13", Journal of Biblical Literature 136 (2017) 529-537.

Hornsby, T.J. - Stone, K. (red.), Bible Trouble. Queer Reading at the Boundaries of Biblical Scholarship (Semeia Studies. Society of Biblical Literature 67; Atlanta, GA: Society of Biblical Literature 2011).

Jodzio, H., „Zjawisko prostytucji w Starym Testamencie w etycznej ocenie autorów biblijnych”, Ruch Biblijny i Liturgiczny 67/4 (2014) 317-343.

Joosten, J., „People and Land in the Holiness Code: An Exegetical Study of the Ideational Framework of the Law in Leviticus 17-26 (Supplements to Vetus Testamentum 67; Leiden: Brill 1996).

Joosten, J., „A New Interpretation of Leviticus 18:22 (par. 20:13) and its Ethical Implications”, The Journal of Theological Studies 71/1 (2019) 1-10.

Kongregacja Nauki Wiary, Uwagi dotyczące projektów legalizacji związków między osobami homoseksualnymi, https://www.vatican.va/roman_curia/congregations/cfaith/documents/ rc_con_cfaith_doc_20030731_homosexual-unions_pl.html [dostęp: 01.05.2021].

Lemański, J., „Negatywny obraz psa w Biblii. Przyczyny i konsekwencje”, Colloquia Theologica Ottoniana 1 (2011) 51-96

Lemański, J., „ «Zapłata psa» (Pwt 23,19) - znaczenie i kontekst społeczno-kulturowy pewnej trudnej wypowiedzi biblijnej”, Pies w kulturach świata (red. E. Skorupska-Raczyńska et al.) (Gorzowskie Studia Bestiograficzne 1; Gorzów Wielkopolski: Wydawnictwo Naukowe Państwowej Wyższej Szkoły Zawodowej 2012) 49-64.

Lemański, J., „(Post-)deuteronomistyczny zakaz transwestytyzmu (Pwt 22,5)? Pytanie o jego właściwy sens i motywacje”, Collectanea Theologica 90/1 (2020) 77-104 (wersja ang.: 
„[Post])Deuteronomistic Prohibition of Transvestitism [Deut 22:5]? The Question of Its Actual Meaning and Motivations", Collectanea Theologica 90/5 [2020] 123-151).

Leuenberger, M., „Geschlechterrollen und Homosexualität im Alten Testament”, Evangelische Theologie 80/3 (2020) 206-229.

Long, G.A., „נָָָָ", New International Dictionary of Old Testament Theology and Exegesis (red. W.A. VanGemeren) (Carlisle U.K.: Paternoster 1996) III, 149-150.

Mathias, S., „Queering the Body: Un-desiring Sex in Leviticus”, The Body in Biblical, Christian and Jewish Texts (red. J.E. Taylor) (London - New York - New Delhi: Bloomsbury Clark 2015) 17-40.

Milgrom, J., Leviticus 17-22. A New Translation with Introduction and Commentary (The Anchor Bible; New York: Doubleday 2000).

Nissinen, M., Homoeroticism in the Biblical World (Minneapolis, MN: Fortress Press 1998).

Olyan, S.M., „'And with a Male You Shall Not Lie the Lying Down of a Woman': On the Meaning and Significance of Leviticus 18,22 and 20,13", S.M. Olyan, Social Inequality in the World of the Text. The Significance of Ritual and Social Distinctions in the Hebrew Bible (Göttingen Oakville: Vandenhoeck \& Ruprecht 2011) 57-83 (= Journal of the History of Sexuality 5 [1994] 179-206).

Papieska Komisja Biblijna, Naród żydowski i jego Święte Pisma w Biblii chrześcijańskiej (tł. R. Rubinkiewicz) (Kielce: Verbum 2002).

Papieska Komisja Biblijna, Czym jest człowiek? Zarys antropologii biblijnej (tł. H. Witczyk) (Kielce: Jedność 2020).

Rogers, J., Jesus, the Bible, and Homosexuality. Explode the Myths, Heal the Church (Louisville, KY: Westminster John Knox 2009).

Römer, T., „Homosexualität und die Bibel. Anmerkungen zu einem anachronistischen Diskurs”, Jahrbuch für biblische Theologie 33 (2018) 47-63.

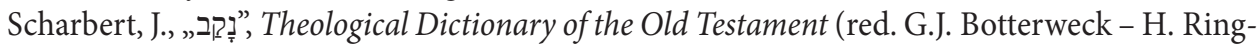
gren) (Grand Rapids, MI - Cambridge: Eerdmans 1998) IX, 551-553.

Schenker, A., „What Connects the Incest Prohibitions with the Other Prohibitions Listed in Leviticus 18 and 20?", The Book of Leviticus. Composition and Reception (red. R. Rendtorff - R.A. Kugler) (Supplements to Vetus Testamentum 93; Leiden - Boston: Brill 2003) $162-185$.

Sklar, J., „The Prohibitions Against Homosexual Sex in Leviticus 18,22 and 20,13: Are They Relevant Today?", Bulletin for Biblical Research 28/2 (2018) 165-198.

Slawik, J., „Czy w Starożytnym Izraelu istniała prostytucja sakralna? Qedešah w Starym Testamencie”, Scriptura Biblica et Orientalia 3 (2011) 45-65.

Snyman, S.D., „Help Levitikus 18:22 en 20:13 die (NG) Kerk in die Debat oor Homoseksualiteit?”, Old Testament Essays 19/3 (2006) 968-981.

Sprinkle, J.M., „Sexuality, Sexual Ethics”, Dictionary of the Old Testament. Pentateuch (red. T.D. Alexander - D.W. Baker) (Downers Grove, IL - Leicester: InterVarsity Press 2002) 741-753.

Stark, C., "Kultprostitution" im Alten Testament? Die Qedeschen der Hebräischen Bibel und das Motiv der Hurerei (Orbis Biblicus et Orientalis 221; Fribourg: Academic Press - Göttingen: Vandenhoeck \& Ruprecht 2006). 


\section{BARBARA STRZAŁKOWSKA}

Stipp, H.J., „Die Qadešen im Alten Testament”, Die Erzväter in der biblischen Tradition, Fs. M. Köckert, (red. A.C. Hagedorn - H. Pfeiffer) (Beihefte zur Zeitschrift für die alttestamentliche Wissenschaft 400; Berlin - New York: De Gruyter 2009) 209-240.

Strojnowski, J. - Greniuk, F., „Homoseksualizm”, Encyklopedia katolicka. VI. Graal - Ignorancja (red. J. Walkusz et al.) (Lublin: TN KUL 1993) 1194-1195.

Strzałkowska, B., Rozporządzenia dotyczące kobiet w Kpł 15 (Rozprawy i Studia Biblijne 20; Warszawa: Vocatio 2006; wyd. 2, 2018).

Strzałkowska, B., „Księga Kapłańska w Septuagincie”, Collectanea Theologica 80/4 (2010) 67-84.

Strzałkowska, B., „Księga Rodzaju w Septuagincie”, Biblica et Patristica Thoruniensia 4 (2011) 95-121.

Strzałkowska, B., „Kobiety w świetle przepisów Księgi Kapłańskiej”, Collectanea Theologica $83 / 2(2013)$ 5-44.

Strzałkowska, B., „Przemoc wobec kobiet w świetle przepisów Tory?”, Biblica et Patristica Thoruniensia 8/2 (2015) 9-29.

Swart, C. - Human, D., „Hoe Bruikbaar is Levitikus 18 en 20 in die Homoseksualiteitsdebat?”, Old Testament Essays 21/2 (2008) 455-481.

Töyräänvuori, J., „Homosexuality, the Holiness Code, and Ritual Pollution: A Case of Mistaken Identity", Journal for the Study of the Old Testament 45/2 (2020) 236-267.

Tronina, A., Księga Kapłańska. Wstęp, przekład z oryginału, komentarz (Nowy Komentarz Biblijny. Stary Testament 3; Częstochowa: Edycja Świętego Pawła 2006).

Vasey, M., Strangers and Friends. A New Exploration of Homosexuality and the Bible (London: Hodder \& Stoughton 1995).

Walsh, J.T., „Leviticus 18:22 and 20:13: Who Is Doing What to Whom?”, Journal for Biblical Literature 120 (2001) 201-209.

Wenham, G.J., The Book of Leviticus (The New International Commentary on the Old Testament 3; Grand Rapids, MI: Eerdmans 1979).

Wenham, G.J., „The Old Testament Attitude to Homosexuality”, Expository Times 102 (1991) 359-363.

Wold, D.J., Out of Order. Homosexuality in the Bible and the Ancient Near East (Grand Rapids, MI: Baker 1998). 